\title{
Pengaruh Islam dalam Kesenian Setrek di Magelang
}

\author{
Langen Bronto Sutrisno ${ }^{1}$ \\ Jurusan Pendidikan Seni Rupa, Fakultas Bahasa dan Seni, Universitas Pendidikan Ganesha, \\ Singaraja - Bali
}

\begin{abstract}
Setrek adalah jenis kesenian tradisional terbangan atau slawatan yang berfungsi sebagai media dakwah agama Islam. Sebagai jenis kesenian tradisional slawatan, perpaduan unsur-unsur estetis seni yang bernafaskan Islam dengan unsur-unsur estetis kesenian rakyat tradisional merupakan akulturasi budaya yang mencerminkan bentuk kreativitas lokal. Pengaruh seni Islam tidak dimaksudkan untuk merubah wujud keseluruhan koreografinya, tetapi lebih merupakan formalitas nilai Islam dalam wajah kesenian tradisional untuk tujuan dakwah. Oleh karena itu bentuk penyajiannya tetap dalam format tradisi dengan sedikit sentuhan nafas Islam. Misalnya penyajian gerak tari hampir tidak dijumpai nafas Islam kecuali gerak takbiratul ihram Allohu Akbar, tokoh Kyai Ba’in yang merupakan refresentasi seorang ulama dengan tata busana khas Islam, iringan diberi nafas Islam dengan syair-syair kitab Al Barjanzi dilengkapi instrumen terbang dan jidor mewakili musik Islam. Nafas Islam sebenarnya lebih merupakan legalitas spirit Islam dalam kesenian setrek dengan harapan semua pemain dan penonton dapat mengamalkan agama Islam dalam kehidupan sehari-hari. Oleh karena itu media dakwah dapat dilihat dalam setiap ungkapan nilainilai ajaran Islam berkait dengan Tuhan Allah SWT dan Rosul-Nya Nabi Muhammad SAW. Dengan demikian setiap gerak dan musik iringan atau syair dalam kesenian setrek harus dijiwai nilai-nilai ajaran Islam. Ikon-ikon demikian penting untuk dipahami agar mereka dapat selamat hidup di dunia dan di akhirat. Kehadiran agama Islam dalam nafas perkembangan kesenian setrek tampak memperkaya penampilannya, sehingga kehadiran kesenian ini dalam kehidupan masyarakat semakin menumbuhkan kualitas dalam beragama Islam, meskipun disadari sisa-sisa kepercayaan kuno masih mewarnai kesenian setrek, seperti atraksi ndas-ndasan yang berupa atraksi mengimitasi binatang. Variasi atraksi arak-arakan $n d a s-n d a s a n$ dengan mengelilingi dusun bertujuan untuk mengusir pengaruh roh-roh jahat.
\end{abstract}

Keywords: setrek, kesenian Islam, slawatan.

\begin{abstract}
Islam influence on Setrek art in Magelang. Setrek is a type of traditional terbangan art or slawatan (Islamic song) that serves as a medium for preaching Islam. As a kind of traditional slawatan art, it seems to blend Islamic aesthetic elements with aesthetic traditional elements which become a form of cultural acculturation reflecting the local creativity. The influence of Islamic art is not intended to change the overall form of the choreography, but the Islamic elements are more of Islamic value formality in the form of traditional arts for the purpose of preaching Islam religion. Therefore, the form of presentation remains in the format of Islamic tradition. For example, the presentation of dance movement hardly finds Islam influence except takbiratul ibram Allohu Akbar, KyaiBain as the representation of Islam priest wearing typical Islamic outfit; the music is also Islamic with given poems from Al Barjanzis book equipped with terbang and jidor. Islam infuence is actually more of a Islamic spirit legacy in setrek art with the hope that all the players and audience can practice Islam in their daily lives. Therefore, the preaching media of Islam can be seen in any expression of Islamic values in relation to Allah SWT and His diciplesNabi Muhammad SAW. Thus every movement and musical accompaniment or poem in setrek art should be imbued the values of Islam. Icons, thus, are important to understand so that the people can live safely in this world and in the hereafter. The presence of Islam in the breath of the setrek artistic development looks enriching its performance, so the presence of this art among the people living in Kedungan III improves the quality of embracing Islam, although there are the remnants of ancient beliefs which still characterize setrek art, such as ndas-ndasan attraction in the form of imitating animal. Variations in ndas-ndasan attraction parade around the village aims to expel the infuence of evil spirits.
\end{abstract}

Keywords: setrek, Islam music, slawatan.

1 Alamat korespondensi: Prodi Seni Rupa Universitas Pendidikan Ganesya. Jalan Ahmad Yani No. 67 Singaraja, Bali, 81116. HP: 08180260 1572, Email: langenbronto@yahoo.com 


\section{Pendahuluan}

Agama Islam yang menjadi agama mayoritas saat ini, banyak memberikan pengaruh terhadap budaya dan seni pada khususnya. Perkembangan Islam dijelaskan Holt, dengan berawal di Sumatera pada menjelang akhir abad ke-13, pemeluk agama Islam berkembang di Indonesia, yang dengan menanjak mempengaruhi wilayahwilayah pantai Jawa serta pulau-pulau lainnya pada abad ke-15 dan ke-16. Sembilan puluh persen penduduk Indonesia adalah Muslim. Pada awal abad ke-16 di Jawa Tengah sebuah dinasti Muslim menghidupkan kembali Mataram sebagai kesultanan. Pada abad ke-18, ketika kekuasaan Belanda menyusup, Mataram telah menjadi kecil dibagi menjadi kerajaan Surakarta dan Yogyakarta, yang secara umum melestarikan kekuasaan secara umum (2000: XXIII-XXIV). Lebih lanjut Holt menjelaskan bahwa persebaran kepercayaan dan budaya India, abad I atau II M sampai abad XVI dan penyebaran Islam, sejak kurang lebih tahun 1250 hingga sekarang (2000: XXII-XXIV). Pengaruh Islam di Jawa begitu kuat, seni pertunjukan yang dianggap syirik dilarang dalam Islam. Upaya yang dilakukan supaya tidak menyimpang dari nilai-nilai Islam, maka seni pertunjukan diberi nilai Islami. Bahkan ada bentuk-bentuk seni pertunjukan yang memang bertujuan sebagai siar Islam.

Seni pertunjukan yang bernafaskan Islam salah satunya adalah kesenian rakyat tradisional setrek. Kesenian setrek berkembang di dusun Kedungan III, Sambeng, Borobudur, Magelang, merupakan seni terbangan atau slawatan. Kesenian dengan penggolongan kesenian rakyat, menurut Soedarsono (2002: 3) dikemukakan bahwa adapun di kalangan rakyat jelata, berkembang seni pertunjukan rakyat (folk performing arts). Sedangkan pada bagian jenis terbangan menurut Kuntowijoyo (19861987: 12) kesenian dimasukkan ke dalam jenis terbangan atau slawatan kerena setidaknya di dalamnya terdapat instrumen jidor dan terbang sebagai unsur yang menunjukkan instrumen yang biasa dipakai dalam seni pertunjukan bernafas Islam, yaitu dalam slawatan. Kesenian setrek menggunakan instrumen jidor dan terbang yang dipadukan dengan instrumen kendang, dodok, kecer, dan seruling. Di luar aspek seninya, jenis kesenian slawatan berfungsi sebagai media dakwah penyebaran agama Islam. Bentuk penyajian berupa perpaduan gerak tari, akrobatik dan musik terbangan yang syairnya memadukan syair bahasa Arab, Jawa dan Indonesia. Perpaduan unsur-unsur estetis seni pertunjukan yang bernafaskan Islam dengan seni pertunjukan tradisi merupakan bentuk kreativitas kolektif dari proses dialektika budaya dalam spirit komunal untuk membangun identitas seni budaya lokal. Spirit komunal dalam kesenian setrek sebenarnya tidak dapat dipisahkan dengan kehadiran kyai Ba'in atau Pangeran Jakaloka seorang pedakwah agama Islam yang diyakini sebagai cikal bakal masyarakat setempat. Demikian ini diperkuat dengan sebuah makam yang diyakini oleh masyarakat setempat sebagai tempat peristirahatan terakhir kyai Ba'in. Menghubungkan tokoh kyai sekaligus Pangeran merupakan bentuk pembenaran secara sosial dan politik untuk menjaga legalitas leluhur dan peninggalan keseniannya.

Apakah kyai Ba'in ketika membangun pedusunan Kedungan atau Klepu disertai dengan membawa kesenian slawatan, tampaknya juga sulit untuk diketahui secara pasti. Namun setidaknya ada peninggalan makam tokoh agama Islam lokal dan kesenian setrek di dusun Kedungan menunjukkan bahwa pengaruh nafas Islam dalam kesenian rakyat tradisional telah berjalan dalam waktu yang cukup lama. Kehadiran kesenian setrek dalam kehidupan masyarakat sesungguhnya menjadi bagian dari kehidupan sistem sosialbudaya masyarakat pendukungnya, terutama berkait dengan berbagai kegiatan dakwah Islam dan upacara adat. Demikian ini tercermin dalam pra pertunjukan kesenian setrek, bahwa sebelum pertunjukan dimulai biasa dilakukan proses ziarah ke makam kyai Ba'in dengan maksud mengirim doa. Dikemukan Kayam (1981: 63) seni tradisional adalah bentuk seni dalam kenikmatan lanskap (lanscap) yang agraris dan feodal, yakni mengabdi kepada harmoni serta keseimbangan abadi dari sang kosmos. Masyarakat setempat mempercayai bahwa ziarah ke makam kyai Ba'in akan membawa berkah. Perilaku spiritual ini sebenarnya merupakan ekspresi masyarakat dalam menjaga keseimbangan kehidupan masyarakat dari gangguan pengaruh buruk, dan mengharapkan ketentraman dan kesejahteraan bagi seluruh warganya. Sebenarnya perilaku tersebut adalah bentuk akulturasi dalam 
kehidupan sistem sosial-budaya. Ritual-ritual yang menyertai pertunjukan tetap dilaksanakan, namun demikian tetap memasukkan nilai-nilai Islam. Upacara ritual adat dengan menyertakan kesenian tradisi yang dimilikinya menunjukkan bahwa peran seni tradisi dalam menjaga keutuhan simbolis semesta.

Seberapa besar pengaruh Islam dalam kesenian setrek sebenarnya dapat diamati dan diketahui dari bentuk penyajiannya. Gerak tari sebagian besar gerak pencak yang biasa dipakai oleh ulama di pondok pesantren untuk melatih fisik santri-santrinya agar tetap sehat jasmani. Di samping itu juga bentuk syair yang mengadaptasi kesenian Islam dengan mengambil dari kitab $\mathrm{Al}$ Barjanzi, yang mengisahkan perjuangan Nabi Muhammad SAW ketika melawan kaum Qurais. Syair-syair ini disadur untuk lagu-lagu kesenian slawatan setrek, demikian juga dengan jenis instrumen seperti jidor dan terbang yang diyakini mewakili kesenian Islam. Menurut Kuntowijoyo (1988: 238) kemungkinan besar pemilihan jenis instrumen seperti jidor dan terbang karena ringan mudah dibawa, sehingga mempermudah dalam berdakwah untuk penyebaran agama Islam yang berpindah dari satu tempat ke tempat lain. Terlepas dari kepentingan penyebaran dakwah, barang kali pertimbangan estetika Islam mengacu pada kualitas estetis dan karakteristik unsurunsur pembentuknya.

Cerita kisah perjalanan hidup cikal bakal dusun Klepu atau Kedungan III yaitu kyai Ba'in atau Pangeran Jakaloka ketika mengembara dan menetap dengan memberi ilmu tantang agama Islam yang bermanfaat bagi kehidupan masyarakat Kedungan III, merupakan tema yang dipilih. Pementasan kesenian setrek diawali dengan pembukaan, dilanjutkan gerak pencak silat dalam posisi penari berbanjar, pada bagian tengah pertunjukan terdapat srokal, dan diakhiri berbagai atraksi akrobatik. Tampilnya tokoh Islam lokal kyai Ba'in tentu saja mempengaruhi pembentukan simbol-simbol estetis yang bernafaskan Islam, terlebih adanya syair yang berbahasaArab, Indonesia, dan Jawa sesungguhnya dalam kesenian setrek terjadi akulturasi. Syair dalam puji-pujian yang berupa sholawat Nabi Muhammad SAW adalah suatu justifikasi tentang nilai ke-Islaman dalam kesenian tradisional. Adapun suasana Jawa atau Indonesia sebenarnya dilatar belakangi oleh kehidupan lokal. Meskipun penganut Islam sebagai mayoritas, namun kepercayaan kejawen atau sinkretisme masih tercermin dalam pembentukan simbol-simbol estetisnya. Percaya pada roh leluhur, percaya pada roh binatang, serta percaya pada hal yang bersifat magi. Masyarakat Kedungan masih termasuk Islam abangan dan Islam santri, yang secara penggolongannya sulit untuk dibedakan. Islam yang demikian menurut Geertz (1989: 7) disebut dengan setengah masyarakat Islam dan setengah kejawen termasuk abangan. Simbol-simbol estetis yang nampak merupakan pertemuan antara varian abangan dan sntri, sekalipun kesenian setrek masuk kategori jenis slawatan. Bentuk kepercayaan itu tercermin dalam upaya memanggil roh setempat menggunakan syair slawatan dengan mengadakan arak-arakan ndasndasan. Bentuk arak-arakan ndas-ndasan semacam ini, terpengaruh oleh adanya seni pertunjukan sekitar di luar seni pertunjukan setrek, yaitu seni pertunjukan ndayakan yang berkembang subur di wilayah Borobudur.

Nafas Islam dalam syair yang merupakan salah satu aspek pembentuk kesenian setrek, dapat diamati contohnya sebagai berikut:

Ya matho kadrot salaungala wairi basar $2 x$

Tuhan limun Tuban $2 x$

Ya Tuhan limun Tuhan masa Amir wairil basar

\section{Terjemahan:}

Wahai pembuat takdir selamatkanlah ia dan seluruh manusia $2 \mathrm{x}$

Tuhan selamatkan Tuhan $2 \mathrm{x}$

Ya Tuhan selamatkan Tuhan seluruh masyarakat dan seluruh manusia

Syair berbahasa Arab namun terlihat sederhana dengan pelavalan yang masih sangat kental dengan dialeg jawa. Syair berbahasa Arab dimaksudkan untuk menunjukkan adanya nafas Islam. Selain berbahasa Arab, setrek juga menggunakan syair-syair berbahasa Jawa dan Indonesia, untuk mempermudah komunikasi dan nilai-nilai syiar dapat tersampaikan bagi para pemain dan penontonnya.

Pengaruh Islam dalam elemen tata busana, terlihat penggunaan busana oleh tokoh kyai Ba'in. Tokoh ini menggunakan busana di antaranya: surban, surjan, kain, stagen, kamus timang, dan 
keris. Surban adalah bentuk pengaruh Islam, yang dulunya banyak dikenakan oleh kaum kyai sehingga identik dengan busana Islam. Sedang busana surjan, kain, stagen, kamus timang dan keris, adalah busana tradisional yang lebih dulu ada.

Untuk dapat mengamati pengaruh Islam dalam kesenian setrek perlu diamati dari keseluruhan bentuk pertunjukannya, menyangkut gerak tari, iringan, tata busana serta aspek-aspek lain pembentuknya. Inspirasi ini merupakan bagian dari penelitian deskriptif kualitatif. Untuk mengkajinya lebih mendalam, penelitian menggunakan pendekatan Antropologi. Pengamatan pada fenomena yang berkembang dalam kesenian setrek, maka pertanyaan mengarah pada bagaimana pengaruh Islam dalam kesenian setrek di dusun Kedungan III, Sambeng, Borobudur, Magelang.

\section{Kesenian Setrek di dusun Kedungan III, Sambeng, Borobudur, Magelang}

Kesenian setrek di dusun Kedungan III, Sambeng, Borobudur, Magelang dalam perjalanannya mengalami dua periode, yaitu sebelum tahun 1961 dan sesudah tahun 1961. Sebelum tahun 1961 menurut tradisi lisan telah ada dan tidak diketahui secara pasti kapan kesenian setrek muncul di lingkungan Kedungan III. Periode sesudah tahun 1961, kesenian setrek telah diolah atau dikreasi kembali oleh beberapa tokoh warga setempat dengan mengacu bentuk setrek yang telah lebih dulu ada. Jauh sebelum tahun 1961 tradisi lisan berkembang dengan mengaitkan kisah kyai Ba'in sebagai cikal bakal masyarakat setempat. Tradisi lisan juga menyebutkan bahwa Kyai Ba’in atau Pangeran Jakaloka adalah seorang bangsawan dari Kraton Kasunanan Surakarta yang mengembara dan bertapa di Goa Gondopura Wangi yaitu di sekitar pegunungan Menoreh. Akhirnya kyai Ba'in menetap di wilayah tersebut sebagai cikal bakal masyarakat setempat. Adapun bentuk petilasan kyai Ba'in terdapat adanya Goa Gondopura Wangi di dusun Gempal, desa Kenalan, Borobudur, Magelang dan makam kyai Bain di dusun Kedungan III, Sambeng, Borobudur, Magelang. Kyai Bà in datang ke dusun Kedungan III, mengajarkan ilmu Islam karena dimungkinkan masyarakat dusun Kedungan masih tipis beribadah dalam memeluk agama.
Kyai Ba'in membangun desa dan mengajarkan agama Islam, pencak silat, tari dan slawatan. Kesemuanya dipadukan meskipun dalam bentuk yang sangat sederhana, berupa gerak yang tidak terikat aturan, dan iringan slawatan, serta busana yang masih sangat sederhana.

Sesudah tahun 1961 tokoh masyarakat setempat Almarhum Kasan Suhadi dan Ahmad Rejo mengkreasi setrek menjadi bentuk seni yang telah baku. Gerak berupa gerak pencak, penari kurang lebih 25-30 orang (terdiri dari mayoritas penari putra dan beberapa penari putri), serta pemusik 8 orang. Bentuk kreativitas berorientasi pada gerak pencak, gerak ini diyakini secara turun temurun merupakan warisan yang bersumber dari ajaran kyai Ba'in. Cerita yang menghiasi kesenian setrek juga terinspirasi dari kisah perjalanan cikal bakal dan perannya yang dianggap penting bagi masyarakat. Penggunaan istilah setrek itu sendiri oleh masyarakat dimaknai menghubungkan atau mengetrekkan, yang artinya menggabungkan budaya Islam dengan budaya tradisional.

Sebelum membahas kesenian setrek lebih lanjut, terlebih dahulu dipandang perlu mengetahui kondisi sosial budaya masyarakat Kedungan, tempat kesenian itu tumbuh dan berkembang. Gambaran wilayah Kedungan memiliki kondisi terjal mendaki, jauh dari keramaian kota serta diselimuti hawa dingin. Masyarakat penduduk adalah masyarakat petani yang tekun bekerja dan beribadah, serta memiliki semangat sosial yang tinggi. Kondisi tenang serta waktu luang yang dimanfaatkan oleh masyarakat untuk berkarya seni, menjadikan sangat wajar jika kesenian setrek berkembang dengan baik. Pelaksanaan berkreasi biasa dilaksanakan pada malam hari, supaya tidak mengganggu masyarakat dalam bekerja bercocok tanam di siang hari. Pendukung kesenian setrek mayoritas berasal dari masyarakat petani, keadaan demikian menjadikan bentuk kesenian yang muncul tampak sederhana.

Selain kesenian setrek, Borobudur juga memiliki beragam kesenian rakyat, antara lain: jathilan, ndolalak, ndayaan, kobrasiswa, soreng, lengger, dan lain sebagainya. Di antara kesenian yang ada di wilayah Borobudur, sebagian dari kesenian yang ada adalah bernafaskan Islam, demikian ini menunjukkan bahwa budaya Islam cukup luas berkembang di wilayah ini. Bukan tidak mungkin Islam juga mempengaruhi 
kesenian lain yang berada di wilayah Borobudur. Kesenian setrek berada pada wilayah kecamatan Borobudur, berada dekat dengan peninggalan Budha yaitu candi Borobudur, namun demikian agama yang berkembang justru mayoritas Islam dan minoritas katolik. Masyarakat Kedungan mayoritas beragama Islam, namun demikian mereka juga masih mempercayai sinkretisme. Kepercayaan tersebut antara lain percaya pada kekuatan arwah leluhur dan menghormati arwah leluhurnya itu. Adat masyarakat dengan mengadakan ziarah ke makam kyai Ba'in sebagai cikal bakal sebagai bentuk pengoperasionalan perintah Allah. Ziarah kubur memiliki maksud mendoakan orang yang telah meninggal dan mengirimkan pahala berupa bacaan dari ayatayat Al Quran dan kalimat-kalimat thayyibah, seperti tahlil, tahmid, tasbih, dan shalawat. Berziarah kepada makam ulama merupakan bentuk tindakan yang dianggap penting untuk dilakukan. Ziarah kubur menurut syariat Islam adalah termasuk amal shalih, amal perbuatan yang baik. Tindakan ini penting untuk dilakukan sebagai salah satu ibadah bentuk spiritual. Ciriciri tradisional muncul bahwa kepemimpinan kyai Ba'in dipercaya akan membawa berkah, sehingga ziarah ke makam tokoh tersebut dipercaya membawa berkah bagi keberlangsungan masyarakat setempat. Menurut pendapat Mas'ud untuk menjaga ciri-ciri tradisional seperti hubungan intim guru-murid yang didasarkan atas suatu sistem kepercyaan daripada hubungan patron-klien yang berkembang luas di masyarakat. Para santri menerima kepemimpinan kyai karena percaya pada konsep dalam masyarakat berkah atau barakah yang didasarkan atas dokrin atau istimewa dari seorang alim atau wali (Anasom, ed, 2004: xvii). Dengan demikian masyarakat menerima kepemimpinan kyai Ba'in karena percaya pada konsep berkah yang didasarkan atas dokrin status istimewa. Bentuk kunjungan pada makam kyai Ba'in, dengan maksud memohon berkah. Demikian juga pengeramatan pada kuburan atau makam itu sendiri. Kebudayaan yang masih berbau sinkretis dan syirik. Menurut Amin (2000: 87) secara etimologi, sinkretisme adalah berasal dari perkataan syin dan kretiozein atau kerannynai, yang berarti mencampur elemen-elemen yang saling bertentangan. Adapun pengertiannya adalah suatu gerakan di bidang filsafat dan teologi untuk menghadirkan sikap kompromi pada hal-hal yang agak berbeda dan bertentangan. Selain itu dikemukakn Prasetyo dikutip Farida (Amin, 2000: 185) bahwa Islam Jawa sering dipandang sebagai Islam sinkretis atau Islam nominal, yang konsekuensinya Islam Jawa bukanlah Islam bukan dalam arti sebenarnya, atau "kuarng Islam", bahkan "tidak Islam". Dengan demikian kepercayaan pada roh leluhur serta pengeramatan makam, bukan dipandang sebagai simbol estetis Islam, karena simbol yang ada adalah simbol yang dianggap menyekutukan Allah, berlawanan dengan tauhid atau ke-Esaan Allah.

Ziarah dengan pembacaan doa-doa, kadang kala disertai dengan pembakaran kemenyan dengan tujuan doa-doanya dapat dikabulkan serta sebagai sarana menyembah pada Allah. Pada dasarnya ziarah adalah bentuk tuntunan Islam, namun di samping itu sinkretisme sebagai budaya Jawa juga tidak begitu saja ditinggalkan. Menurut Sofwan (Anasom, ed, 2004: 5) sebenarnya keadaan demikian pada mulanya merupakan bentuk pengIslaman terjadi secara damai karena metode yang dipakai dalam berdakwah menggunakan unsur-unsur budaya lama (Hinduisme dan Buddhisme), tetapi secara tidak langsung memasukkan nilai-nilai Islam ke dalam unsur-unsur lama itu. Oleh karenanya pembakaran kemenyan dipakai juga oleh para kyai dengan pemahaman sebatas sebagai pengharum ruangan ketika seorang muslim berdoa sehingga doa akan khusyuk. Pemehaman ini berbeda dengan kayakinan masyarakat Kedungan yang menganggap bahwa bau kemenyan adalah bau yang disukai oleh roh, sehingga dipercaya dapat segera hadir dan akan memberikan berkah bagi yang hidup.

Semenjak berdiri tahun 1961 dan masa-masa perkembanganya, seni ini mulai mendapatkan tempat di hati masyarakat. Peristiwa yang tidak kalah penting, bergejolak di masyarakat pada masa perkembangan kesenian setrek dengan adanya akibat meletusnya G-30-S PKI. Ketakutan meletusnya G-30-S PKI tahun 1965, menjadikan masyarakat berlari mengejar identitas agama, tujuannya supaya terhindar dari keterlibatan G-30-S PKI. Pemerintah Indonesia memberlakukan adanya pemberantasan G-30-S PKI sampai ke akar-akarnya. Meski Islam menjadi pencarian identitas, namun demikian unsur- 
unsur budaya lama (Hinduisme dan Buddhisme) tidak serta merta hilang, dan memasukkan nilainilai Islam dalam penampilannya. Masyarakat menganggap budaya lama adalah budaya leluhur yang layak dipertahankan. Perkembangan kesenian setrek, semakin berani menunjukkan identitas ke-Islamannya. Apalagi pasca meletusnya G-30-PKI, sekitar 1965-1966 ketika di Indonesia terjadi huru-hara G-30-S PKI. Akibat yang mendasar dari sekedar peristiwa politik dan militer, terjadi transformasi sosial dan budaya yang menyentuh akar terbawah, sehingga muncul kecenderungan spiritual. Bentuk kesenian setrek merupakan upaya masyarakat sebagai pencarian pengakuan diri sebagai umat Islam. Berkesenian dengan nafas Islam sebenarnya adalah upaya pendukung kesenian sebagai bentuk legitimasi bahwa masyarakat pendukungnya dominan beragama Islam. Saifuddin (2006: 356) secara umum mengemukakan bahwa para ilmuwan memandang legitimasi sebagai bentuk-bentuk kekuasaan atau dominasi.

Kesenian setrek yang bernafas Islam dalam kondisi dan situasi huru-hara, tampaknya mempermudah seni ini untuk dapat diterima di masyarakat. Kesenian setrek sebagai media penyebaran Islam, tampaknya tidaklah terlepas dari upayanya untuk lebih memperkenalkan secara mendalam nilai-nilai Islam. Pemahaman tentang nilai-nilai yang boleh dilakukan dan yang tidak boleh dilakukan. Perbuatan mengagungagungkan selain Allah, dan bersekutu dengan setan adalah perbuatan yang dianggap syirik. Kesenian setrek tetap dipertahankan, sebagai penghormatan dan pengakuan terhadap Islam, dengan membawa misi syiar Islam, meskipun terkadang dalam penampilannya terdapat berbagai nilai kepercayaan lama.

Untuk dapat mengamati seberapa besar pengaruh Islam dalam kesenian setrek, dikaji melalui pengamatan dari keseluruhan bentuk penampilannya. Menurut Soedarsono, bentuk penyajian dalam hubungannya dengan tari, mempunyai pengertian cara menyajikan atau cara menghidangkan suatu tarian secara menyeluruh oleh unsur-unsur atau elemen pokok dari pendukung dalam tari (1978: 23). Elemenelemen tersebut adalah prosesi pembuka, gerak, tata rias dan busana, tempat pertunjukan, properti tari, dan iringan. Elemen-elemen tersebut akan membentuk adanya perwujudan bentuk penyajian dari suatu tari. Menjelang pementasan kesenian setrek, dilakukan persiapan terlebih dahulu. Bentuk persiapan adalah ziarah ke makam cikal bakal kyai Ba'in. Ziarah dianggap berarti karena dipercaya membawa berkah bagi masyarakat pendukungnya. Ziarah bagi pertunjukan juga dipercaya akan memdapatkan kelancaran dan kemeriahan atas izin dari leluhurnya. Jika persiapan dirasa telah dipenuhi, maka prosesi pementasan akan segera dilaksanakan.

Bentuk sajian seni pertunjukan setrek diawali prosesi pembuka yang dipimpin oleh salah satu pendukung seni, dengan pembacaan surat $\mathrm{Al}$ Faatihah. Dengan harapan diberi kelancaran, kemudahan, diberikan jalan yang terbaik, sehingga bermanfaat bagi pementasan dan kelangsungan hidup masyarakat setempat. Elemen-elemen seni pertunjukan yang meliputi gerak, desain lantai, tata rias busana, iringan, durasi, arena pementasan, serta perlengkapan, dikemukan berikut secara berturut-turut. Gerak diawali arak-arakan ndasndasan, berupa gerak berjalan sesuai irama musik pengiring dan syair solawat. Motif dalam gerak berjalan arak-arakan, menyajikan motif langkah kanan dan langkah kiri dilakukan dengan kedua tangan di atas, atau kadang kala berlenggang. Apabila binatang yang diperankan berkaki empat, maka kedua tangan difungsikan sebagai kaki. Motif langkah kanan langkah kiri dilakukan tidak terhingga atau sepanjang melakukan perjalanan arak-arakan. Frase pada bagian arak-aran adalah dari dimulainya arak-arakan hingga berakhirnya arak-arakan. Penampilan yang mengimitasi binatang di antaranya kambing, sapi, kerbau, badak, zebra, dan harimau. Selain penari arakarakan ndas-ndasan, juga disajikan permainan akrobatik berupa permainan api.

Pada arena pentas, secara umum disajikan gerak pencak dan beberapa gerak akrobatik dengan berbagai variasi. Sajian berupa pertunjukan rakyat dengan komposisi tari yang sederhana, sesuai pengetahuan tari yang dimiliki. Menurut Soedarsono pengetahuan komposisi tari atau koreografi adalah pengetahuan teknik menggarap gerak tubuh manusia di ruang pentas menjadi satu bentuk pertunjukan tari (1976: 3). Dikemukakan Soedarsono lebih lanjut bahwa karena taritari rakyat disusun untuk kepentingan rakyat setempat, peraturan koreografi yang nampaknya 
sulit itu tidak dirasakan keperluannya. Dengan lain perkataan komposisi tari-tarian rakyat cukup sederhana saja, sebab nanpaknya yang penting bukanlah presentasi yang artistik tinggi dan yang harus dinikmati dengan perhatian yang serius pula. Rakyat daerah dalam melanjutkan tradisi tari-tarian rakyat lebih didasarkan oleh adanya dorongan kebutuhan rokhani yang menyangkut kepercayaan-kepercayaan adat dan lain sebagainya (1976: 3).
Kesenian setrek melanjutkan tradisi taritarian rakyat lebih didasarkan oleh adanya dorongan kebutuhan rokhani yang menyangkut keyakinannya pada agama Islam. Gerak diawali tampilnya tokoh kyai Ba'in, gerak sesaat memasuki arena pementasan adalah dengan berjalan ke arena pementasan, hormat, takbiratul ihram, dan duduk bersila. Adapun motif dan unit syair gerak takbiratul ihram kyai Ba'in sebagai berikut:

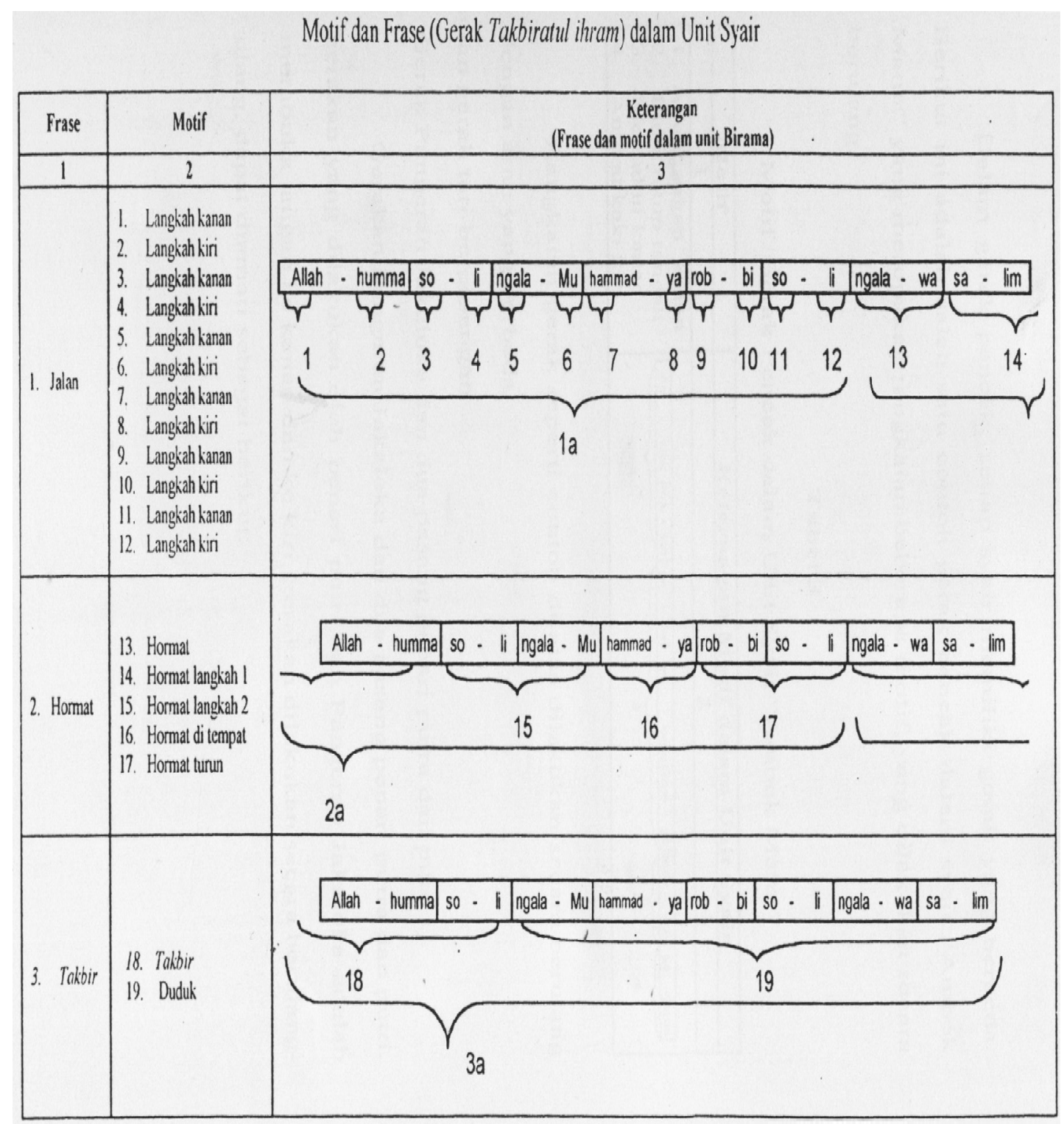

Usai gerak hormat dan takbiratul ihram oleh kyai Ba'in, pertunjukan dilanjutkan dengan gerak pencak oleh penari berbanjar dan kyai Ba'in sebagai pemimpin gerak. Dalam gerak pencak, setiap satu judul syair memiliki gerak yang berbeda. Sajian penampilan setrek dipadukan dengan gerak tari kreasi oleh beberapa penari anak-anak, serta variasi permainan atraksi.
Adapun atraksi meliputi: memukul kepala dengan bambu, menghancurkan kelapa di atas perut, mengangkat kursi dengan gigi, berguling di atas duri salak, makan lampu, memecah lampu tanpa disentuh dan tanpa bantuan peralatan apapun, menginjak pecahan lampu, melepaskan tali ikatan tanpa bantuan, dan memainkan kendhang, seruling dengan tangan terikat. 
Sekalipun kesenian setrek difungsikan sebagai media dakwah Islam, namun pertunjukan setrek juga menampilkan trance. Menurut Holt tari-tari trance (tak sadar diri) memerankan peranan penting dalam komunitas dengan kekuatan-kekuatan yang lebih tinggi. Tari-tari ini memiliki banyak fungsi. Seringkali tari-tari itu ditampilkan untuk melawan bencana-bencana seperti epidemi, dan sering kali untuk maksud-maksud misterius dari tari serta kebiasaannya yang aneh menyediakan daya tarik khas bagi umum. Penari trance menikmati prestise yang sungguh-sungguh, karena ketika kerasukan, mereka telah menjadi sarana dari kekuatan supernatural (2000: 125). Sesungguhnya dalam kesenian setrek, dalam keadaan trance, seni ini dianggap sebagai perwujudan dan bentuk media dalam upaya menjalankan kepercayaannya. Peristiwa yang berlawanan sebagai seni siar, masyarakat pendukung seni juga tidak secara serta merta menghilangkan budaya leluhurnya begitu saja. Trance dengan melibatkan dunia magi, maka yang terjadi ketegangan, takut, dan khawatir. Barangkali masyarakat ingin menyeimbangkan kebahagiaan yang dinikmati dalam hidup, dengan dunia yang kasat mata. Supaya tidak terjadi ketimpangan di atara keduanya, ketegangan, ketakutan, dan kekhawatiran yang bergejolak dalam jiwa dapat dinetralisir. Roh yang tak nampak diharapkan datang, ikut bersenang-senag dengan menari-nari melalui media tubuh manuisa yang masih hidup dalam ketidak sadaran. Trance merupakan peristiwa tak sadarkan diri, maka gerak yang sering kali muncul gerak yang tak terstruktur dan tidak beraturan. Gerak yang sering kali muncul merupakan tarian makluk yang tak nampak merasuki penari.

Penyembuhan trance dalam kesenian setrek menggunakan mantra oleh pawang atau pemimpin spiritual. Menurut Holt pimpinan ini biasanya seorang tua dan guru mistik. Menenangkannya dan dengan serta merta membawanya keluar dari trance dengan kemenyan dan mengkomat-kamitkan mantera-mantera (2000: 128). Tindakan-tindakan baik pelaku trance maupun pawang merupakan bentuk sisa-sisa dari kepercayaan animismedinamisme. Simuh mengemukakan bahwa religi animisme-dinamisme tentu membutuhkan golongan pawang yang berfungsi sebagai pendeta yang bisa berhubungan langsung dengan roh-roh dan menguasai kekuatan gaib, sebagai perantara, dukun, orang tua, atau pendeta. Religi animismedinamisme memuncak dengan pengembangan ilmu perdukunan, ilmu klenik, ilmu gaib dengan rumusan lafal-lafal yang dipercaya berdaya magis (Anasom, ed, 2004: 21). Demikian ini dalam Islam dianggap syirik, dan dilarang dalam Islam. Upaya yang dilakukan supaya tidak menyimpang dari nilai-nilai Islam, maka kesenian setrek diberi sentuhan nilai Islam.

Untuk memahami komposisi kesenian setrek, perlu diamati aspek pembentuk seni. Menurut Soedarsono bahwa aspek-aspek dan elemenelemen koreografi yang berguna sekali bagi pembinaan tari-tarian rakyat. Dari sekian banyak elemen koreografi yang betul-betul berguna bagi pembinaan tari-tarian rakyat adalah desain lantai, desain atas, dinamika, dan disain kelompok, sebab sebagian besar dari tari-tarian rakyat berbentuk tari kelompok (group choreography) (1976: 4). Desain lantai kesenian setrek menggunakan desain lantai sederhana. Menurut Soedarsono, desain lantai adalah garis-garis di lantai tari yang dilalui oleh seorang penari atau garis-garis di lantai tari yang dibuat oleh formasi penari-penari kelompok. Pada dasarnya hanya ada dua pola garis dasar pada lantai, yaitu garis lurus dan garis lengkung (1976: 4). Secara garis besar desain lantai dalam kesenian setrek menggunakan desain garis lurus untuk gerak pencak, dan desain melingkar pada gerak kyai Ba'in dan penari binatang. Soedarsono mengemukakan bahwa desain lantai yang menggunakan garis-garis lurus memberikan kesan kesederhanaan tetapi kuat (1976: 5). Penampilan gerak-gerak pencak menggunakan desain lurus tampak sederhana dalam penampilannya tetapi kuat. Soedarsono juga mengemukakan bahwa desain lantai yang menggunakan garis lengkung memberikan kesan lembut dan menarik. Dalam koreografi tari-tarian rakyat desain lengkung ini dipakai untuk memberi bumbu agar keseluruhan koreografi nikmat dan nyaman untuk ditonton (1976: 5). Tampaknya penampilan kyai Ba'in dan penari binatang dengan desain melingkar memberikan kesan lembut dan menarik.

Desain yang perlu diamati dalam pertunjukan tari rakyat adalah desain atas. Menurut Soedarsono, desain atas (air design) adalah garis-garis yang ditimbulkan oleh gerak dan pose anggota badan penari dan properti tari yang nampak pada ruang yang berbeda di atas lantai tari. Desain 
atas ini bisa dibuat dengan kaki, tubuh (torso), dengan lengan dan tangan beserta jari-jarinya, dengan kepala dan juga dengan properti tari atau perpaduan dari semuanya (1976: 5). Desain atas yang terbentuk dalam kesenian setrek, khususnya gerak-gerak pencak baik yang dibawakan oleh kyai Ba'in ataupun penari pencak, banyak dibuat oleh perpaduan kaki, tubuh (torso), lengan dan tangan, serta kepala.

Kemenarikan dalam kesenian setrek, berada pada dinamika tari, baik dinamika dalam garapan tari maupun dinamika dalam diri penari. Dinamika menurut Soedarsono adalah kekuatan dari sebuah garapan atau koreografi tari yang bisa menimbulkan daya pukau bagi yang menyaksikan (1976: 8). Tidak semua penari memiliki dinamika diri, karena dinamika diri merupakan karunia dari Tuhan. Namun demikian dikemukakan Soedarsono bahwa banyak teknikteknik tari yang dapat menolong sebuah garapan menjadi menarik yaitu dengan dinamika buatan (1976: 9). Penelitian ini hanya akan mengemukakan dinamika buatan yang terdapat dalam kesenian setrek. Sebagai pedoman awal untuk dapat mengemukakan dinamika dalam kesenian setrek, perlu dipahami masing-masing unsur yang terdapat dalam dinamika. Soedarsono mengemukakan bahwa untuk dinamika buatan ini sering dipinjam istilah-istilah musik untuk mempermudah pengertian di antaranya, accelerando adalah tehnik dinamika yang dicapai dengan mempercepat tempo gerak dan juga tempo iringan musiknya. Ritardanto adalah tehnik dinamika yang dicapai dengan memperlambat tempo gerak tari atau iringan musiknya. Crescendo adalah teknik dinamika yang dapat dicapai dengan memperkeras atau memperkuat gerak atau iringan musiknya. Decrescendo adalah tehnik dinamika yang dicapai dengan memperlambat gerak atau iringan musiknya. Piano ialah tehnik dinamika yang dapat dicapai dengan menggarap gerak-gerak mengalir atau iringan musiknya yang mengalir. Forte adalah tehnik dinamika yang dicapai dengan garapan gerak yang menggunakan tekanan-tekanan yang bisa lebih diperkuat dengan tekanan-tekanan pada iringan musiknya. Staccato adalah tehnik dinamika yang dapat dicapai dengan menggarap gerak menjadi patah-patah. Legato adalah tehnik dinamika yang dapat dicapai dengan garapan gerak yang mengalun (1976: 9).
Hampir semua unsur dinamika dipergunakan dalam kesenian setrek, demikian ini terjadi karena kesenian setrek terdapat berbagai macam variasi gerak. Di antaranya unsur accelerando, ritardanto, crescendo, decrescendo forte, dan staccato terdapat pada gerak-gerak pencak dan penari ndas-ndasan, sedangkan unsur piano dan legato terdapat pada gerak tarian kreasi.

Kesenian setrek secara keseluruhan disajikan dengan menampilkan desain kelompok. Unsur desain kelompok menurut Soedarsono dibagi dalam tiga kelompok yaitu serempak (unison), berimbang (balanced) dan selang-seling (alternate). Yang dimaksud dengan desain kelompok serempak ialah desain yang dibuat dengan desain lantai yang satu, bergerak melangkah ke arah yang sama, serta menggunakan desain atas yang sama pula. Desain ini akan memberikan kesan teratur. Desain kelompok berimbang ialah disain yang membagi penari kelompok menjadi dua kelompok yang sama, masing-masing kelompok ditempatkan pada dua desain lantai yang sama, dan gerak ke arah yang sama pula. Desain ini selain memberi kesan teratur juga kesan isolasi pada masing-masing kelompok. Desain kelompok selang-seling adalah desain yang menggunakan pola selang-seling pada desain lantai dan desain atas (1976: 9). Ketiga unsur desain kelompok yaitu desain unison, balaced, dan alternate terdapat banyak ditemukan pada kesenian setrek di bagian penampilan gerak pencak. Kesenian setrek tampak memiliki kesan teratur, kompak, isolasi dan berselang-seling.

Untuk dapat memahami kesenian setrek secara menyeluruh, akan dikemukakan elemenelemen pembentuk tari tara rias dan busana. Kesenian setrek menggunakan tata rias dan busana sederhana. Secara umum tata rias penari putra dengan mempertebal alis dan kumis, menggunakan pemerah bibir dan pipi, serta rias cantik untuk penari putri. Cara penggunaan make up juga sesuai pengetahuan pelakunya. Alat-alat make up juga masih sangat sederhana, terdapat satu paket make up yang dipergunakan secara bersama-sama. Pada penari binatang tidak menggunakan tata rias, karena telah menggunakan tiruan kepala binatang yang menutupi wajahnya. Karakterisasi seni pertunjukan ini dapat diamati pada penggunaan tata busananya. Tata busana penari binatang berupa tiruan kepala binatang, 
baju sekaligus celana panjang dengan motif menyerupai kulit binatang, dan krincing pada kaki. Tata busana tokoh kyai Ba'in menggunakan busana surban, lis pada kepala, surjan, kain, kaos kaki, dan sepatu sendal. Tata busana penari putra pada gerak pencak menggunakan iket kepala, manukan, kaca mata, baju lengan panjang, rompi, kace segi tiga, kaos tangan, stagen, kain, celana, kaos kaki dan sendal bertali. Tata busana putra pada tari kreasi anak menggunakan iket kepala, kaca mata, kace segi tiga, baju putih lengan panjang, celana hitam lengan panjang, dan sepatu. Tata busana penari putri menggunakan lis kepala, kebaya, kamus dan kain. Tata busana penari akrobatik menggunakan iket kepala, baju pencak, celana pencak, dan sabuk. Tata busana pemusik menggunakan topi, baju lengan panjang putih, celana panjang hitam, rompi, dan sepatu.

Pengiring kesenian setrek berupa instrumen yang berasal dari alat musik dan syair yang dinyanyikan. Alat musik dalam kesenian setrek terdiri dari 1 jidor, 1 dodok, 1 kendhang (berbentuk klenthing), 3 terbang, 3 bendhe, 1 penthong, 1 kecer, 2 seruling, dan 1 peluit. Teknik memainkan alat musik diperlukan stamina yang baik, karena dalam memainkannya membutuhkan tenega serta kepekaan irama dalam permainannya. Memainkan alat musik, khususnya terbang dilakukan bergantian, supaya dalam memainkannya pemusik tidak merasa kelelahan. Irama musik dapat dibedakan apabila gerak berubah, sajian iramanyapun selalu berulang. Dikemukakan Haviland pengulangan dalam sajian musik tidak memberikan tekanan pada observasi, tetapi memberinya suatu bentuk simbolis suatu kenyataan atau kekekalan (1988: 238). Hampir di seluruh sajian penampilan musik kesenian setrek terdapat pengulangan, demikian ini merupakan suatu bentuk simbolis suatu kenyataan atau kekekalan.

Kesenian setrekjuga diiringi syairyang dinyanyikan secara bersama oleh para penyanyinya. Syair menggunakan bahasa Arab, Jawa, dan Indonesia, meskipun terkadang penggunaan bahasa Arab yang kurang sempurna dalam pelavalannya, karena pengaruh dialeg Jawa. Penggunaan bahasa Jawa ataupun Indonesia, bertujuan supaya mempermundah dalam berkomunikasi menyampaikan pesan siar Islam.
Durasi, arena pentas dan properti kesenian setrek, diurai secara berturut-turut sebagai berikut. Durasi penyajian kesenian setrek \pm 5 sampai 6 jam, durasi yang panjang tersebut dikarenakan kesenian setrek memiliki beberapa bagian yang setiap bagiannya memiliki jeda serta penampilan gerak tari yang diulang-ulang. Pementasan seni pertunjukan setrek dilaksanakan di arena pentas yang telah diberi pembatas bambu. Bagian yang membutuhkan properti, di antaranya pada gerak tari kreasi oleh anak-anak dan pada bagian atraksi. Pada tari kreasi oleh anak-anak menggunakan properti payung, boneka, dan kendi. Properti dalam permainan atraksi di antaranya tongkat (bambu), meja, lampu, duri salak, kursi, tali, kain, dan rantai beserta kunci gemboknya.

Fungsi seni pertunjukan setrek dalam masyarakat memiliki berbagai macam keperluan, Koentjaraningrat mengemukakan pengertian fungsi dalam kebudayaan adalah segala aktivitas kebudayaan itu sebenarnya bermaksud memuaskan suatu rangkaian dari sejumlah kebutuhan naluri makhluk yang berhubungan dengan kebutuhannya (1981: 171). Fungsi kesenian setrek di antaranya: sebagai pelengkap upacara keagamaan, sebagai pelengkap upacara adat, dan sebagai hiburan. Seni pertunjukan setrek dalam pelengkap upacara keagamaan, di antaranya sebagai pelengkap peringatan Maulud Nabi, pelengkap peringatan Idul Fitri, dan pelengkap peringatan Idul Adha. Seni pertunjukan setrek sebagai pelengkap upacara adat, di antaranya berkait dengan daur hidup manusia, berupa: kelahiran, khitanan, dan perkawinan. Kesenian setrek juga sebagai pelengkap upacara adat seperti nazar dan bersih desa. Pada umumnya pelaksanaan upacara adat dengan dilengkapi tarian terdapat pada masyarakat yang menganut sistem kepercayaan. Soedarsono mengemukakan tari yang berfungsi sebagai sarana upacara adat terdapat di daerah yang masih kuat unsurunsur kepercayaan kunonya (1977: 184). Tidak jarang kesenian setrek sebagai hiburan semata. Kuntowijoyo mengemukakan seni dan hiburan merupakan kebutuhan pokok hidup manusia baik sebagai individu, kelompok masyarakat, karena cara, jiwa dan keyakinannya berbeda-beda, maka sudah barang tentu corak, macam dan ragamnya bentuk seni serta hiburannyapun bermacammacam pula, sesuai dengan lingkungannya 
(1986-1987: 23). Bentuk hiburan di lingkungan masyarakat Kedungan dengan menonton seni pertunjukan setrek. Arti dari suatu hiburan itu sendiri dalam kamus Antropologi (Suyono dan Siregar, 1985: 145) merupakan aktivitas untuk menyegarkan kembali jasmani dan pikiran setelah bekerja keras berupa permainan olah raga, menonton pertunjukan, melaksanakan kesenangan pribadi, mengobrol dengan teman dan lain sebagainya.

Jika diamati secara rinci, setrek difungsikan sebagai pelengkap upacara agama, pelengkap upacara adat, dan sebagai hiburan, namun secara umum dalam setiap penampilannya bertujuan menyampaikan pesan dakwah Islam. Dakwah menurut Gazalba berasal dari bahasa Arab, diamati dari segi logat berarti menyeru dan mengajak (Madya dan Gazalba, 1988: 158). Dakwah Islam dalam kesenian setrek dengan adanya ikon bacaan Al Faatihah dan syair Al Barjanzi. Inti dari kalimah menunjukkan kebenaran Islam, serta perintah menjalankan ajaran Islam, menjauhi segala larangannya.

\section{Pengaruh Islam dalam Kesenian Setrek}

Islam merupakan agama yang tumbuh dan berkembang dengan pesat di Indonesia. Berbagai bidang telah banyak terpengaruh oleh Islam. Madya (1988: 19) mengemukakan bahwa Qur'an menyebut Islam 'dien', ungkapan bahasa Semit dan Arab. Dien dalam bahasa Semit berarti undang-undang atau hukum. Dalam bahasa Arab kata ini mengandung arti menguasai, menundukkan, patuh, hutang, balasan, kebiasaan. Menurut Razak Islam berasal dari kata salama, yang artinya menyerah, tunduk dan patuh, untuk mendapatkan salam, artinya keselamatan atau kedamaian. Menyerah, tunduk dan patuh kepada Tuhan yang menciptakan semua yang ada dalam kehidupan ini, bukan menyerah, tunduk dan patuh kepada hawa nafsu serta kepentingankepentingan materi. Hanya dengan menyerah, patuh dan tunduk kepada Allah-lah yang akan membawa keselamatan, kedamaian (Noor, 2003: 16). Pemahaman yang berpijak pada pengertianpengertian tersebut, manusia sebagai umat Allah hendaknya tunduk dan patuh pada perintahNya, dan menjauhi laranganNya, tidak menuruti pada hawa nafsu dan kepentingan materi duniawi. Islam banyak mempengaruhi bidang lain. Penyebaran Islam di Jawa dilakukan secara lunak dan halus, sehingga nilai-nilai Islam dapat diterima dengan baik oleh masyarakat. Soedarsono (2002: 3839) mengemukakan bahwa pengaruh Islam mulai tampak jelas di Indonesia sejak abad ke13 dan berkembang dengan pesat sekali sampai abad ke-18 dengan penyebaran yang sangat demokratis. Islam menurut hubungannya di antara lingkungannya, menurut Madya (1988: 22), Dien (Islam) mengatur dua pola hubungan. Tiap perkara yang menyangkut kedua hubungan itu masuk dalam ruang lingkup Dien Islam. Sistem hubungan pertama membentuk agama, sedang sistem hubungan kedua membentuk budaya Islam, yaitu keduanya dapat diamati sebagai berikut:

Sesuai dengan skema di atas, terdapat hubungan antara manusia dan manusia sebagai pembentuk kebudayaan. Kebudayaan setidaknya memiliki asas agama, supaya terjadi suatu keseimbangan dalam pembentukan kebudayaan. Agama dijadikan sebagai asas kebudayaan hendaknya membentuk ketauhidan bagi pemain dan penonton, agar meningkatkan keimanan dan ketakwaan. Aspek kebudayaan menurut Madya (1988: 26-27) adalah untuk salam kebendaan di dunia, yang pantulan nilainya ujud di akhirat. Agama berpusat pada iman kepada tauhid (keEsaan Tuhan), dan kebudayaan berasaskan agama (dokrin agama menentukan asas kebudayaan).

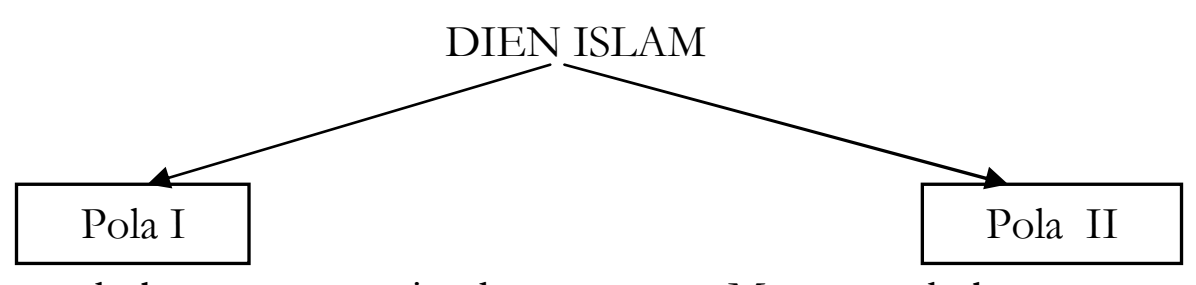

Mengatur hubungan manusia dengan Tuhan, yang membentuk agama
Mengatur hubungan manusia dan manusia, yang membentuk masyarakat sebagai penjelma kebudayaan 


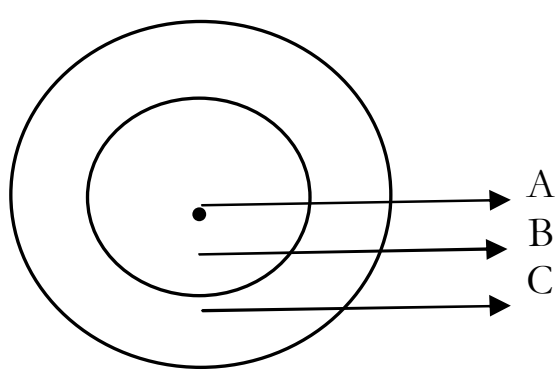
Keterangan
A : Tauhid ; Asas Agama
B : Agama ; Asas Kebudayaan
C : Kebudayaan

Dien Islam : Perpaduan antara Tauhid+Agama+Kebudayaan

Norma kebudayaan diputuskan oleh ijtihad (ijtihad adalah berfikir yang membentuk kebuadayaan Islam dengan merujuk secara langsung maupun tidak langsung).

Adapun skema Dien Islam dijelaskan sebagai berikut:

Berdasarkan skema di atas, dien Islam adalah perpaduan antara tauhid, agama, dan kebudayaan. Pengaruh Islam dalam seni, sebagai bagian dari kebudayaan, kiranya sangat menentukan ekspresi estetis ke-Islamannya. Menurut Al-Faruqi estetika Islam itu sendiri adalah pandangan tentang keindahan yang muncul dari pandangan dari dunia tawhid yang merupakan inti ajaran Islam, yaitu keindahan yang dapat membawa kesadaran penanggap kepada ide transendental. Pernyataan tentang ke-Esaan dan transendensi-Nya menurut Al-Faruqi dikenal dengan Tawhid (secara literer berarti "meng-Esa-kan") (1999: vii). Pandangan demikian akan dikaji dalam kesenian tradisional kerakyatan sehingga dapat mengaitkan pengaruh Islam ke dalam seni tersebut. Menurut Anshari estetika Islam tentang seni adalah estetika yang mengacu pada nilai-nilai dasar dan kaidah-kaidah asasi Islam tentang permasalahan seni (Yustiono, dkk: 1993, 31). Dengan demikian ekspresi estetis ke-Islaman dalam kesenian setrek akan tercermin dalam simbol-simbol yang bernafas ke-Islaman, dengan pemaknaan yang mengacu pada kaidah-kaidah Islam. Menurut Herusatoto simbol berasal dari kata Yunani symbolos, yang berarti tanda atau ciri yang memberikan sesuatu hal kepada seseorang. Simbol-simbol estetis Islam kesenian setrek yang terdapat dalam elemenelemen pembentuknya (1983: 10). Kesenian setrek memiliki nilai-nilai kebaikan sesuai dengan tuntunan Islam agar beriman dan bertakwa kepada Allah, menjalankan segala perintahNya dan menjauhi segala laranganNya.
Simbol estetis Islam dalam prosesi pembuka, melavalkan surat Al Faatihah. Harapan yang dipanjatkan menjelang pementasan supaya diberikan keselamatan dari mulai hingga berakhir pementasan. Al Qur'an dan terjemahannya (Q.S. Al Fatihaah; Muqaddimah) bahwa Al Fatihah dinamakan "Ummul Qur'an” (induk Al Qur'an) atau "Ummul Kitab" (induk Al Kitab), karena merupakan induk bagi semua isi Al Qur'an, serta menjadi inti sari dari kandungan Al Qur'an. Al Faatihah yang dibacakan menjelang pementasan kesenian setrek, supaya nilai-nilai Al Qur'an yang telah terangkum di dalamnya, dapat diamalkan oleh para pendukung seni dan penontonnya.

Pengaruh Islam dalam kesenian setrek dapat diamati dari elemen-elemen pembentuknya, di awali dengan pengamatan pengaruh Islam terhadap gerak. Kesenian setrek diawali gerak takbiratul ihram yang dilakukan oleh tokoh kyai Ba'in. Takbiratul ibram dengan bacaan "Allaahu Akbar", artinya Allah Maha Besar. Gerak takbiratul ihram dalam kesenian setrek, memiliki gerak seperti akan melakukan sholat dengan gerakan mengangkat kedua tangan, menghadap ke arah kiblat, dilakukan dengan khidmat dan khusyu'. Gerak takbiratul ihram menunjukkan adanya simbol estetis Islam. Kesenian setrek menggunakan gerakan takbiratul ihram sebagai tanda dimulainya shalat, dengan bacaan "Allahu Akbar"yang artinya "Allah Maha Besar", yang diucapkan dalam hati, dilakukan secara khusyu'. Simbol takbiratul ihram dalam kesenian setrek memiliki makna bahwa umat muslim wajib menyembah kepada Allah serta mengakui kebesaran-Nya. Gerak takbir yang ditunjukkan dalam kesenian setrek dilakukan 
dengan khusyu', dengan harapan permintaan yang dipanjatkan terkabulkan.

Simbol estetis Islam juga terdapat pada gerak pencak. Dirunut dari kehidupan pencak itu sendiri, menurut Maryono jika diamati dari dua loci (tempat) utama pelajaran ilmu silat, yaitu keraton dan mandala. Pada awalnya di keraton, ilmu pencak silat bela diri hanya diperuntukkan bagi anggota keluarga raja dalam rangka mempersiapkan mereka menjalankan tugasnya sebagai pembela kerajaan (2000: 50-51). Namun keadaan demikian tidaklah selamanya stabil, atau pastinya pembaharuan dan perubahan akan terjadi. Menurut Maryono, pendidikan tidak lagi bersifat kejuruan, bukan saja bersifat ketentraman saja, melainkan bertujuan pembentukan kualitas kepribadian manusia. Dalam peralihan aspek spiritual yang dari mulanya dikandung secara implisit akhirnya didominasi aspek bela diri. Di keraton Jawa misalnya, kaitan pencak silat dengan wawasan kosmologi manunggaling kawula Gusti (kesatuan manusia dengan Tuhan). Walau dipergunakan untuk yang bersifat praktis, sebagai pendukung kemahiran praktis, sebagai pendukung kemahiran fisik dalam peperangan, ilmu batin mulai diutamakan sebagai sarana untuk mencapai kesatuan manusia dengan Tuhan (2000: 51). Ini menunjukkan adanya suatu bentuk pengakuan gerak pencak dalam kesenian setrek bersumber dari budaya keraton, atau bentuk pengakuan tokoh Pangeran Jakaloka sebagai wujud pembenaran dari kaum bangsawan. Perkembangan pencak, merembet pada kalangan abdi keraton. Menurut Maryono, walaupun masyarakat umum masih belum terjangkau, pencak silat bersama unsur spiritualnya mulai diajarkan di keraton kepada abdi dalem (pelayan) dan kawula (orang yang diperintah) menurut kedudukan masing-masing dalam hirarki. Ketegasan aspek spiritual pencak silat, serta meluasnya di luar kalangan bangsawan, juga terpengaruh oleh penyebaran Islam di kepulauan Nusantara yang dibawa masuk oleh para pedagang muslim dari Gujarat, Arab, dan mungkin dari Cina. Demikian pula, pencak silat mempunyai peran dalan proses Islamisasi di pulau Jawa. Sembilan Wali di Jawa adalah yang merintis pondok pesantren di Jawa dengan melanjutkan tradisi mandala dari agama-agama terdahulu. Selain sebagai pembelaan di kalangan pesantren, pencak merupakan bagian itegral dari ajaran agama. Dalam suatu proses yang menuntut santri menjadi manusia yang bertakwa kepada Tuhan Yang Maha Esa. Ilmu pencak digabungkan dengan tenaga batin yang bersumber dan digali dari kalimah-kalimah suci Al-Qur'an, khususnya pencak silat digunakan untuk "amar ma'ruf nahi mungkar" yang berarti mengajak orang ke jalan kebaikan dan mencegah kesesatan (2000: 52-54). Tidak mengherankan ketika kesenian setrek juga menghadirkan atraksi dalam penampilannya. Bentuk pembuktian bahwa ilmu batin yang dimilikidengan menyajikan atraksiyangberbahaya namun tetap mampu mengatasinya, tidak lain karena kekuasaan Allah. Dalam setiap atraksiatraksinya penari terlebih dahulu memanjatkan doa, supaya dalam melakukan gerak berbahaya mendapat perlindungan dari Allah, karena segala sesuatu bersumber atas kuasa-Nya. Atraksi adalah bagian dari kegiatan mengolah tenaga batin, atraksi adalah suatu bentuk melatih diri berolah kanuragan. Olah batin dalam kehidupan sehari-hari, diharapkan dipergunakan dalam hal kebaikan. Nilai-nalai yang diharapkan mampu dipahami oleh pendukung dan penontonnya, pencak silat dan ilmu batin dapat dipergunakan dalam kebaikan dan mencegah kesesatan.

Penampilan gerak pencak, pada bagian tengah penampilannya terdapat srokal, dimaksudkan sebagai penghormatan kepada Nabi Muhammad SAW. Srokal berisi doa dan syair yang dinyanyikan secara bergantian oleh pengiring dan penari. Gerak penari berdiri berbanjar saling berhadapan, kepala menunduk dilakukan secara khidmad. Menurut Kuntowijoyo (1986-1987: 13) bagian srokal merupakan adegan yang mengisahkan datangnya Nabi ke Madinah, dan seolah-olah yang sedang menari berdiri menyongsong kedatangan Sang Nabi. Harapan ditujukan bagi pendukung tari dan penontonnya, supaya manusia bertakwa kepada Allah, mempercayai Nabi Muhammad sebagai utusan Allah.

Simbol-simbol estetis Islam kesenian setrek yang terdapat pada elemen penokohan adalah tokoh kyai Ba'in. Ada beberapa istilah kyai menurut Dhofier dikutip Faqih dalam "Khasanah Budaya Jawa”, salah satunya mengemukakan bahwa kyai adalah sebutan untuk orang yang memiliki kedalaman ilmu agama Islam dan memiliki kharisma tertentu, baik yang memimpin pondok pesantren maupun yang hanya sebagai 
tokoh agama (Anasom, ed, 2004: 129-130). Kyai Ba'in sesuai tradisi lisan yang berkembang memiliki kedalaman ilmu agama Islam, bahkan kharismanya dijadikan suri tauladan bagi pengikutnya dan generasinya. Terlihat dengan ajaran Islam yang diajarkannya berkembang dengan baik di lingkungan masyarakat pengikutnya. Sisa-sisa kharisma seorang kyai ditampilkannya tokoh kyai Ba'in dalam kesenian setrek yang masih berkembang dengan baik hingga kini.

Pengaruh Islam dalam elemen musik pengiringnya, bahwa kesenian setrek termasuk dalam jenis seni terbangan atau slawatan. Adanya jidor dan terbang menunjukkan instrumen yang biasa dipakai dalam seni pertunjukan Islam. Menurut Kuntowijoyo kesenian yang dimaksukkan ke dalam seni terbangan atau slawatan, karena unsur terbang sebagai instrumen musik dikenal sejak masuknya Islam di Indonesia, dan menjadi khas bagi seni musik Islam. Kesenian Islam selalu ditandai alat-alat musik yang ringan, merupakan instrumen yang mudah dibawa dan ringan, dalam upaya siar agama Islam (19861987: 11). Simbol Islam berupa instrumen jidor, merupakan alat untuk menyerukan perintah sholat yang biasa diletakkan dan dibunyikan di Masjid. Instrumen terbang biasa dipergunakan kaum muslim dalam mengiringi syair sholawat berjanzi. Varian golongan terbang ini merupakan tanda khas dari bentuk-bentuk seni ke-Islaman. Istrumen yang dipakai pada masing-masing tradisi musikal merupakan tanda dari golonganNya. Masyarakat Kedungan memanfaatkan musikal terbang merupakan tanda yang lebih mengarah pada golongan masyarakat Islam.

Kesenian setrek selain diiringi instrumen juga disertai syair, dengan tujuan mempermudah komunikasi pemain dengan penontonnya. Syair dinyanyikan oleh 3 orang penyanyi. Syair mengandung petuah dalam hidup yang mengandung nilai-nilai Islami. Setrek juga menggunakan syair-syair berbahasa Jawa, Indonesia, dan Arab. Syair slawatan dalam kesenian setrek digubah dari kitab Al Barjanzi. Syair ini dikenal dikenal di masyarakat hingga kini. Menurut Kuntowijoyo (1986-1987: 11) unsur slawatan dikenal karena seni pertunjukan rakyat itu memakai kitab Al Barzanji sebagai sumber. Sekalipun barzanji itu lebih dari sekedar bacaan slawat atau puji-pujian saja kepada Nabi, yaitu juga berisi kisah-kisah sekitar Nabi, tetapi unsur yang terpenting ialah syair-syair yang memuji kepribadian dan akhlakul karimah atau budi utama Nabi.

Syair kesenian setrek bersumber dari Al Qur'an. Menurut Suryanegara Al Qur'an di dalamanya merupakan pengoperasionalan perintah wahyu dalam bahasa seni, dalam bentuk simbolisasi (Yustiono, ed, dkk: 1993: 393). Dengan demikian syair kesenian setrek merupakan pengoperasionalan perintah wahyu dalam bahasa seni, dalam bentuk simbolisasi. Selain itu menurut Al-Faruqi selain ditentukan oleh ajaran Al Qur'an, seni Islam juga bersifat "Qur'ani" dalam arti bahwa Kitab Suci orang muslim ini menjadi model utama dan tertinggi bagi kreativitas dan produksi estetis. Al Qur'an dinyatakan sebagai "karya seni pertama dalam Islam" (1999: 13). Dalam kesenian setrek menggunakan 3 bahasa yaitu Jawa, Indonesia, dan Arab. Bahasa Jawa dan Indonesia di dalamnya tetap mengandung nilai-nilai Islam, dengan maksud memudahkan penyampaian pesan syair, karena tidak semua masyarakat penonton memahami makna syair dalam bahasa Arab.

Beberapa contoh syair kesenian setrek dalam bahasa Jawa, Indonesia, dan Arab serta terjemahannya sebagai berikut:

Agama kito sudahlah terang

Nderek dawuhe dari Pangeran

Dawuhe Nabi amal yang baik

Karo agami podho nindakke

Sungguh kami sekalian

Karena main malam

Minta ampun kepada Allah

Sebab kami main berdiri

Tapi Allah suka

Kami saudara

Kan menjadi rohmatul Islam

Kan berdiri jika bertemu

Sholla tulla salla mullah 'ala thoha Rosulillah

Sholla tulla salla mullah 'ala yasin habibillah

Agama kita sudahlah terang

Ikut perintah dari Pangeran

Perintah Nabi amal yang baik

Dengan agama semua menjalankan 
Keselamatan dari Allah moga slalu dilimpahkan pada Rosul

Keselamatan dari Allah semoga dilimpahkan atas kekasih Allah (Rosul)

Beberapa syair di atas, menunjukkan simbolsimbol estetis Islam, di dalamnya mengandung nilai-nilai ajaran Islam. Nilai-nilai kebaikan diharapkan dilaksanakan oleh pendukung seni dan penontonnya. Kuntowijoyo mengemukakan bahwa dalam penyajian lagu dalam pentas selalu diiringi dengan anjuran-anjuran, ajaran-ajaran atau dakwah dengan harapan supaya orang berbuat baik selamat hidupnya (1986-1987: 31). Syair-syair kesenian setrek dikreasi dipadu padankan dengan tembang-tembang tradisional, demikian ini sebagai bentuk penyesuaian minat penontonnya dan diharapkan penonton tidak mengalami kebosanan. Makna syair yang variatif diharapkan tetap mengandung siar Islam, semua penonton yang datang tertarik, mencintai Agama, Tuhan, dan Nabi. Menurut Kuntowijoyo kesenian nampak dinamis, dengan syair-syair dan penampilannya banyak digubah, sesuai dengan kepentingan dan jamannya, unsur aslinya tetap utuh sebab mereka takut merubah dari unsur aslinya (1986-1987: 31). Demikian sesuai dengan kesenian setrek digubah dari kitab Al Barjanzi, sesuai dengan kepentingan dan jamannya saat ini, dengan tidak menghilangkan nilai dan makna yang ingin disampaikan.

Simbol-simbol estetis Islam yang terdapat dalam busana, yaitu penggunaan stambul atau surban, menunjukkan busana yang biasa dikenakan oleh kaum ulama. Surban adalah penutup kepala dalam upaya mendekatkan diri kepada Allah. Menutup aurat bagi kaum muslim pria, dan dirasa lebih sopan dalam menghadap Tuhannya. Menurut Suryanegara (Yustiono, ed, dkk, 1993: 390-391) dalam tuntunan Islam yaitu Al-Qur'an menyampaikan ajaran berbusana dengan ciri libasu at-taqwa. Adapun ciri-ciri libasu at-taqwa memiliki 3 kriteria (1) Sebagai busana taqwa dalam pandangan Allah, "Wa libasu at-taqwa zalika khair - dan busana yang demikian itulah yang terbaik". (Q.S. 7:26); (2) Sebagai sarana mendekatkan diri kepada Allah ketika masuk ke masjid, "Ya bani Adam, khazu zinatakum inda kulli masjid - Ya bani Adam kenakanlah busanamu yang indah, di saat memasuki masjid”.
(Q.S. 7:31); (3) Memiliki ukuran yang mampu menutupi keburukan atau kekurangan fisik serta tidak mengekspor perhiasan fisik, "Libasan yuwari sauatikum wa risyan" - busana yang menutupi aurat dan perhiasan" (Q.S. 7:26)

Memahami ketiga kriteria: baik, indah, dan menutupi aurat, Suryanegara juga mengemukakan bahwa dari data sejarah, terlihat bahwa ukuran kelengkapan busana dalam mendekatkan diri terhadap Allah, mengandung tiga unsur utama: Pertama, bersih yang memancarkan keindahan. Kedua, berukuran panjang dan tidak jarang. Ketiga, unsur tidak hanya berlaku bagi wanita, tetapi juga untuk pria (Yustiono, ed, dkk, 1993: 392). Tata busana yang terpengaruh Islam adalah tata busana kyai Ba'in, secara lengkap menggunakan surban/ stambul, surjan, kain, stagen, kamus timang, keris, lis pada kepala, dan sampur. Secara keseluruhan busana yang dikenakan kyai Ba'in baik, indah, dan menutupi aurat. Menutup Aurat pada pria adalah dengan menutup sebagian rambutnya, maka penggunakan surban difungsikan untuk menutup aurat. Di samping sebagai penutup aurat, penggunaan surban mewakili busana Islam, karena biasa dipergunakan oleh kaum ulama. Dikemukan Suryanegara pada masa sesudah Rasulullah Muhammad SAW, pengaruh libasu at-taqwa terlihat pada busana para ulama atau pemimpin agamanya yang terpengaruh oleh perkembangan Islam (Yustiono, ed, dkk, 1993: 392). Surban dalam kesenian setrek dapat dipahami sebagai pengaruh libasu at-taqwa, di samping itu surban juga merupakan salah satu syarat dalam mendekatkan diri kepada Allah, sebagai tudung kepala.

MasyarakatKedungan adalah masyarakatJawa, pengaruh Islam yang begitu halus dalam budaya Jawa tercermin dengan tetap mempertahankan busana Jawa yang telah lebih dulu ada, di samping itu busana Jawa tidak bertentangan dengan nilainilai Islam. Penggunaan busana surjan, kain, stagen, kamus timang, lis pada kepala, sampur, dan keris, merupakan busana tradisional Jawa, namun tetap dapat dimasukkan ke dalam kriteria busana libasu at-taqwa yaitu baik, indah, dan menutup aurat. Busana tradisional menurut Suryanegara bahwa keragaman busana tradisional yang mempunyai daya pengaruh dalam dan berakar, merupakan bukti ketepatan pemilihan kreativitas perancang busana bangsa Indonesia, berakar 
pada penerjemahan ajaran Islam yang disesuaikan dengan kondisi kodrati bangsa Indonesia (Yustiono, ed, dkk, 1993: 392). Demikian pula dalam pemilihan busana dalam kesenian setrek, penggunaan busana tradisional di samping tetap mempertahankan budaya bangsa yang memiliki nilai luhur, juga sebagai bentuk kreativitas yang begitu tinggi. Paduan yang kreatif dengan tidak meninggalkan budaya kodrati, budaya yang telah lebih dulu ada, sekaligus menyajikan busana yang tidak bertentangan dengan kaidah Islam.

\section{Penutup}

Kesenian setrek adalah jenis kesenian tradisional terbangan atau slawatan, yang berfungsi sebagai media dakwah agama Islam di dusun Kedungan III dan sekitarnya. Sebagai jenis kesenian tradisional slawatan, tampaknya perpaduan unsur-unsur estetis seni Islam dipadu dengan unsur-unsur estetis kesenian rakyat tradisional, merupakan akulturasi budaya yang mencerminkan bentuk kreativitas lokal. Pengaruh seni Islam tidak dimaksudkan untuk merubah wujud keseluruhan koreografinya, tetapi unsurunsur nafas Islam lebih merupakan formalitas nilai Islam dalam wajah kesenian tradisional untuk tujuan dakwah agama Islam. Oleh karena itu bentuk penyajian tetap dalam format tradisi dengan sedikit sentuhan nilai Islam. Misalnya penyajian gerak tari hampir tidak dijumpai nafas Islam, kecuali gerak takbiratul ihram Allahu Akbar, refresentasi seorang ulama dengan tata busana khas Islam, iringan diberi nafas Islam berupa syair kitab Al Barjanzi, dilengkapi instrumen terbang dan jidor yang mewakili musik Islam.

Nafas Islam sebenarnya lebih merupakan legalitas spirit Islam dalam kesenian setrek dengan harapan semua pemain dan penonton dapat mengamalkan agama Islam dalam kehidupan sehari-hari. Fungsinya sebagai media dakwah, maka spirit agama Islam dapat dilihat dalam setiap ungkapan nilai-nilai ajaran yang berkaitan dengan Tuhan Allah dan Rosul-Nya Nabi Muhammad SAW. Cerminan jiwa nilai Islam terdapat dalam ekspresi setiap gerak, musik iringan atau vokalnya. Ikon-ikon ini penting untuk dipahami oleh pemain dan penonton sebab adanya nilai-nilai ajaran Islam.

Kehadiran agama Islam dalam nafas perkembangan kesenian setrek tampak memperkaya penampilannya, sehingga kehadiran kesenian ini dalam masyarakat Kedungan III semakin menumbuhkan kualitas dalam beragama Islam, meskipun disadari sisa-sisa kepercayaan kuno masih mewarnai kesenian setrek, seperti atraksi arak-arakan ndas-ndasan yang mengimitasi binatang dilakukan dengan berkeliling kampung, dengan maksud mengusir roh jahat. Demikian ini tampak memperkaya dan menambah semarak rangkaian pertunjukan setrek untuk menghibur warga masyarakat Kedungan III.

Pengaruh ajaran Islam berupa petunjuk akan adanya ke-Esaan Tuhan Allah yang harus disembah. Mengamalkan segala perintahNya dan menjauhi segala laranganNya dalam kehidupan sehari-hari, serta diadaptasi dalam bentuk berkesenian yaitu dalam kesenian setrek. Demikian ini merupakan bentuk pengamalan spiritual Islam dalam tata nilai kesenian tradisi. Sebaliknya, kesenian setrek yang tradisional dikemas dalam nafas Islam sebagai pencerminan masyarakat Kedungan III yang beragama Islam dalam masyarakat budaya Jawa.

\section{Kepustakaan}

Amin, Darori, ed. 2000. Islam dan Kebudayaan Jawa. Yogyakarta: Gama Media.

Anasom, ed. 2004. Merumuskan Kembali Interelasi Islam-Jawa. Yogyakarta: Gama Media.

Suyono dan A. Siregar. 1985. Kamus Antropologi. Jakarta: Akademi Presindo.

Geertz, Clifford. 1989. Abangan, Santri, Priyayi dalam Masyarakat Jawa. Terjemahan Asmad Mahasin. Jakarta: Pustaka Jaya.

Haviland, William A. 1988. Antropologi, Jilid 2. Terjemahan RG. Soekadijo. Jakarta: Erlangga.

Herusatoto, Budiono. 1983. Simbolisme dalam Budaya Jawa. Yogyakarta: Hanindita.

Holt, Claire. 2000. Melacak Jejak Perkembangan Seni di Indonesia. Alih Bahasa R.M. Soedarsono. Bandung: Arti.line.

Kayam, Umar. 1981. Seni, Tradisi, Masyarakat. Jakarta: Sinar Harapan

Koentjaraningrat. 1981. Kebudayaan Mentalitas dan Pembangunan. Jakarta: Gramedia.

Kuntowijoyo, dkk. 1986-1987. Tema Islam dalam Pertunjukan Rakyat Jawa: Kajian Aspek Sosial, Keagamaan dan Kesenian. Yogyakarta: 
Departemen Pendidikan dan Kebudayaan, Direktorat Jenderal Kebudayaan, Proyek Penelitian dan Pengkajian Kebudayaan Nusantara (Javanologi).

Madya dan Gazalba, Sidi. 1988. Islam dan Kesenian, Relevansi Islam dengan Seni-Budaya Karya Manusia. Jakarta: Pustaka Al-Husna.

Maryono, O’ong. 2000. Pencak Silat Merentang Waktu. Yogyakarta: Galang Press.

Noor, Alfian. 2003. Mengenal Islam. Jakarta: El Kahli.

Saifuddin, Ahmad Fedyani. 2006. Antropologi Kontemporer Suatu Pengantar Kritis Mengenai Paradigma. Jakarta: Kencana.
Soedarsono, [R.M. Soedarsono], ed. 1976. Mengenal Tari-tarian Rakyat di Daerah Istimewa Yogyakarta. Yogyakarta: Akademi Seni Tari Indonesia Yogyakarta.

1977. Tari-tarian Indonesia I. Jakarta: Departemen Pendidikan dan Kebudayaan .

1978. Diktat Pengantar dan Pengetahuan Komposisi Tari. Yogyakarta: ASTI.

2002. Seni Pertunjukan Indonesia di Era Globalisasi. Yogyakarta: Gadjah Mada University Press.

Yustiono, ed. 1993. Islam dan Kebudayaan Indonesia, Dulu, Kini, dan Esok. Jakarta: Yayasan Festival Istiglal. 